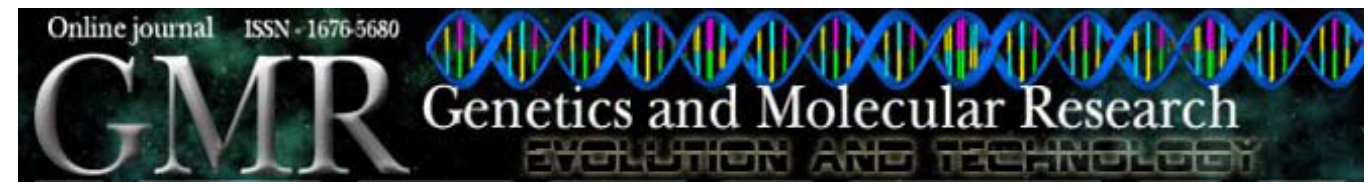

\title{
Sexual recombination in Colletotrichum lindemuthianum occurs on a fine scale
}

\author{
E.A. Souza1, O.A. Camargo Jr. ${ }^{2}$ and J.M.A. Pinto ${ }^{1}$ \\ ${ }^{1}$ Departamento de Biologia, Universidade Federal de Lavras, Lavras, MG, Brasil \\ ${ }^{2}$ Departamento de Agricultura, Universidade Estadual do Centro-Oeste do Paraná, \\ Guarapuava, PR, Brasil
}

Corresponding author: E.A. Souza

E-mail: easouza@dbi.ufla.br

Genet. Mol. Res. 9 (3): 1759-1769 (2010)

Received April 29, 2010

Accepted July 10, 2010

Published September 8, 2010

DOI 10.4238/vol9-3gmr863

ABSTRACT. Glomerella cingulata $\mathrm{f}$. sp phaseoli is the sexual phase of the fungus Colletotrichum lindemuthianum, the causal agent of common bean anthracnose. This fungus is of great concern, because it causes large economic losses in common bean crops. RAPD markers of five populations of G. cingulata f. sp phaseoli from two Brazilian states were analyzed to determine if this population possesses the sexual reproductive potential to generate the genetic variation that is observed in this phytopathogen. We identified 128 polymorphic bands, amplified by 28 random primers. The estimates of genetic similarity in this analysis ranged from 0.43 to 1.00 , and the dendrogram generated from analysis of all genotypes displayed five principal groups, coinciding with the five populations. Genetic differentiation was observed between the populations $\left(G_{S T}=0.6455\right) ; 69 \%$ of the overall observed genetic variation was between individual populations and $31 \%$ of the variance was within the sub-populations. We identified significant levels of linkage disequilibrium in all populations. However, the values of the disequilibrium ranged from low to moderate, indicating that this pathogen maintains a genetic structure consistent with sexual reproduction. The mean contribution of sexual reproduction was determined by comparison of the amplitudes of genetic similarity of isolates from sexual and asexual phases. These results support the 
hypothesis that recombination plays an important role in determining the amplitude of variability in this pathogen population and that this determination occurs on a fine scale.

Key words: Anthracnose; Common bean; RAPD markers; Genetic variability

\section{INTRODUCTION}

The common bean (Phaseolus vulgaris) is a species of great agronomic interest, especially in tropical and subtropical developing countries. With 26.9 million hectares devoted to this crop, Brazil is the world's largest common bean producer (Paula Junior et al., 2008). Diseases are responsible for significant yield losses, and anthracnose is one of the most severe diseases of this crop, causing losses of up to $100 \%$ when contaminated seeds are sown under conditions that favor disease development (Silva et al., 2007).

The fungus Colletotrichum lindemuthianum, the causal agent of anthracnose of the common bean, has been found in many countries in the Americas, Europe, Africa, and Asia; it has considerable pathogenic variability. More than 100 pathotypes of this fungus have been described (Silva et al., 2007). One of the most common and least expensive strategies employed to control anthracnose is the use of cultivars carrying resistance alleles. The success of adopting resistance as a disease control strategy depends on knowledge of the level of variability between and within populations of the pathogen. Information about the processes responsible for high population variability is particularly important for this effort.

It is likely that various separate and simultaneous mechanisms are involved in the amplification of genetic variability of this pathogen. Sexual recombination is an important part of this process (Rodríguez-Guerra et al., 2005; Camargo Jr. et al., 2007). Relevant research has been done on the parasexual cycle (Roca et al., 2003), mutation (Tu, 1992) and transposons (Kistler and Miao, 1992) in this pathogen. Studies on the population structures of both host and pathogen, their respective recombination systems and their interactions in space and time can provide relevant information about the epidemiology of this disease, the relative importance of each mechanism responsible for generating variability and the process of pathogen-host co-evolution (Bock et al., 2005).

The pathogen Glomerella cingulata f. sp phaseoli (the sexual phase of the fungus $C$. lindemuthianum), first described by Shear and Wood (1913), has been identified in field isolates from Brazil (Camargo Jr. et al., 2007). Sexual compatibility studies performed in the laboratory have revealed both homothallic and heterothallic behaviors in different isolates of G. cingulata f. sp phaseoli (Mendes-Costa, 1996; Rodríguez-Guerra et al., 2005; Camargo Jr. et al., 2007).

Studies of the population structure of $C$. lindemuthianum have demonstrated that although reproductive processes in this species are predominantly asexual, the mating patterns of the populations reflect those of random species. In other words, the populations exhibit gametic equilibrium, suggesting that at some points during the host cycle, the pathogen undergoes sexual reproduction (Rodríguez-Guerra et al., 2003). Sexual reproduction allows for the generation of new combinations of alleles in each recombination cycle, leading to a high level of genetic diversity in the pathogen's population. Consequently, periodic occurrence of sexual reproduction can explain much of the variability found in $C$. lindemuthianum populations. 
We evaluated the genetic diversity both within and between populations of G. cingulata f. sp phaseoli isolated from Brazil by random amplified polymorphic DNA (RAPD) analyses. Our objective was to examine the potential for sexual reproduction in this species to generate genetic variability.

\section{MATERIAL AND METHODS}

\section{Collection and maintenance of the isolates and procurement of the monoascosporic cultures}

Five populations of $G$. cingulata f. sp phaseoli were isolated from stems, leaves and pod lesions of the common bean (P. vulgaris). All isolates were obtained without the use of inducers. Material was collected during each of the three seasons of the common bean crop from both experimental and commercial production fields. Three populations were sampled in the State of Minas Gerais, two populations in Lavras (Valente and Majestoso) and one in Lambari (VCU); two populations were sampled in the State of Paraná, Guarapuava and Turvo. The isolates were maintained in $\mathrm{M}_{3}$ media (Junqueira et al., 1984). The methodology described by Camargo Jr. et al. (2007) was used to obtain monoascosporic cultures. Forty random ascospores were isolated from each population, and the cultures were grown in an incubator at a controlled temperature $\left(21^{\circ} \mathrm{C}\right)$ and under controlled light conditions (a 12-h light period per day).

\section{Characterization of $G$. cingulata f. sp phaseoli pathotype}

The 12 differentiated cultivars, as proposed by the International Center of Tropical Agriculture (Centro Internacional de Agricultura Tropical, CIAT, 1990) to identify different pathotypes of $G$. cingulata f. sp phaseoli, were inoculated with spore suspensions of each strain. Sterile pods were inoculated and incubated at $22^{\circ} \mathrm{C}$ for 10 days in the dark to obtain inocula with concentrations of $1.2 \times 10^{6}$ spores $/ \mathrm{mL}$. The ascospore suspensions were sprayed 10 days after sowing ( $4 \mathrm{~mL}$ per plant), followed by incubation in mist chambers at $22^{\circ} \mathrm{C}, 12-\mathrm{h}$ photoperiod and $98 \%$ relative humidity for $48 \mathrm{~h}$. The plants were transferred to a greenhouse, and they were evaluated for symptoms seven days after inoculation, according to the descriptive scale recommended by Rava et al. (1993).

\section{Sexual compatibility test}

Paired crosses were made to examine the sexual behavior (homothallic or heterothallic) of the populations. Ten individuals from each population were used, providing 900 interpopulation combinations. The crosses were performed on Petri dishes containing $20 \mathrm{~mL} \mathrm{M}_{3}$ culture medium, as described by Camargo Jr. et al. (2007).

\section{Obtaining mycelial masses and DNA extraction}

Two hundred monoascosporic isolates were cut into pieces and transferred to Erlenmeyer flasks with $150 \mathrm{~mL} \mathrm{M}_{3}$ liquid medium and chloramphenicol $(0.1 \mathrm{mg} / \mathrm{mL})$. The cultures were maintained on an automatic shaker at a speed of $110 \mathrm{rpm}$ and $22^{\circ} \mathrm{C}$ for five days. Dehydration of the 
mycelial masses was performed with a vacuum pump. Total genomic DNA was extracted from lyophilized mycelium, according to the methodology described by Raeder and Broda (1985). DNA concentrations were estimated with a Hoeffer Scientific TKO100 fluorometer.

\section{RAPD analyses}

RAPD reactions were performed with $200 \mu \mathrm{M}$ dNTPs, 0.6 units Taq DNA polymerase, and $0.4 \mu \mathrm{M}$ primer, in a reaction buffer at $\mathrm{pH} 8.0(50 \mathrm{mM}$ Tris, $2.0 \mathrm{mM} \mathrm{MgCl}, 20 \mathrm{mM} \mathrm{KCl}$, $250 \mu \mathrm{g} / \mathrm{mL}$ bovine serum albumin, $1 \%$ Ficoll 400 , and $1 \mathrm{mM}$ tartrazine), with $20 \mathrm{ng}$ genomic DNA, in a final volume of $15 \mu \mathrm{L}$. The mixture was amplified in a thermocycler programmed for two cycles of $91^{\circ} \mathrm{C}$ for $60 \mathrm{~s}, 42^{\circ} \mathrm{C}$ for $70 \mathrm{~s}$ and $72^{\circ} \mathrm{C}$ for $70 \mathrm{~s}$; then 38 cycles that differed from the first in the denaturation time $(1 \mathrm{~s})$ plus one cycle of $4 \mathrm{~min}$ at $72^{\circ} \mathrm{C}$. Three hundred random primers were tested, and only those repeatedly presenting medium- or high-intensity bands were selected for further analyses. To analyze the DNA fragments, the amplified products were separated on $1.0 \%$ agarose gels in TBE buffer (Tris, boric acid and EDTA) with an electrical current of $100 \mathrm{~V}$ for $2.5 \mathrm{~h}$. The amplified fragments were treated with ethidium bromide $(0.5 \mu \mathrm{g} / \mathrm{mL})$ for $30 \mathrm{~min}$ and were observed under ultraviolet light.

\section{Data analyses}

All RAPD bands were annotated using a binary system with codes of 1 or 0 for the polymorphic bands when they were present or absent, respectively. The estimation of genetic similarity $\left(s g_{i j}\right)$ between each pair of strains was calculated using the Nei and Li coefficient (1979), and the analyses were performed using the NTSYS-PC 2.1 program (Rohlf, 2000). Dendrograms were generated for all populations simultaneously and for each population individually using the method of similarity averages (UPGMA).

The errors associated with each similarity were estimated according to the following expression, modified from Skroch et al. (1992):

$$
\text { Estimated standard error: }\left(s_{s g}\right)=\sqrt{s g_{i j} \frac{1-s g_{i j}}{n-1}}
$$

where $n$ is the sum of $a, b$ and $c$ for each isolate pair.

The genetically different isolates were identified in the dendrogram based on the estimate of the maximum significant similarity value $\left(s g_{m}\right)$. The $s g_{m}$ was estimated by the $t$-test, using the following expression: $s g_{m}=1-\left(t . \bar{s}_{s g}\right)$

where $t$ is the tabled value of the Student $t$-distribution at the $1 \%$ level of probability, with n-2 degrees of freedom, and $\bar{s}_{s g}$ is the mean error of the comparisons considered in the dendrogram.

The number and percentage of polymorphic loci were determined, as were the expected heterozygosity (Nei, 1973) and the Shannon index (1948); the latter was used to estimate the diversity within the populations. This value was also used to determine the diversity attributed to components within the populations. The analyses were performed using the GDA program (Genetic Data Analysis), version 1.0 (http://lewis.eeb.uconn.edu/ lewishome/software.html). 
The ARLEQUIN 2.000 program (Schneider et al., 2000) was utilized for analysis of the molecular variance (AMOVA), considering a hierarchical structure in which isolates derived from the same location were analyzed as a single population. The digenic linkage disequilibrium within the five populations of $G$. cingulata f. sp phaseoli was also calculated using the ARLEQUIN 2.000 program. RAPD bands were considered as unique loci, and the presence or absence of the bands was considered as an allele. The probability for each locus association was tested using the Fisher test with Markov chain methodology (Raymond and Rousset, 1995). Associations with probability less than 0.05 were considered to be significantly different from zero. MULTILOCUS 1.3 (Agapow and Burt, 2001) was used to calculate multilocus connection disequilibrium, $\bar{r}_{\mathrm{d}}$, a modification of the association index, $I_{\mathrm{A}}$ (Brown et al., 1980). The estimate of $I_{\mathrm{A}}$ tests the importance of the clonal and sexual reproduction modes within each population by calculating the distance between all loci pairs and comparing these distances to the linkage equilibrium. However, due to the fact that this estimate is influenced by the number of sample loci, the estimate of $\bar{r}_{\mathrm{d}}$ is preferred, as it is independent of the number of sampled loci (Burt et al., 1999). The $\bar{r}_{\mathrm{d}}$ values were calculated, and a total of 1000 permutations were completed for each population.

\section{RESULTS}

\section{Characterization of pathotypes and crosses between the strains}

The $G$. cingulata f. sp phaseoli isolates were classified as pathotype 0 when artificially inoculated in the 12 differentiating cultivars, since none of the differentiating cultivars presented a compatibility reaction.

No fertile crosses were identified among the crosses between strains of different populations. However, when the strains developed from these populations were grown in isolation on Petri dishes using $\mathrm{M}_{3}$ medium, they produced perithecia with asci and ascospores.

\section{Characterization of the RAPD markers}

Among the 300 random primers tested, 28 repeatedly generated medium- or highintensity bands in the RAPD amplifications of the isolates evaluated. These 28 primers (OP M-1, OP M-2, OP M-3, OP M-4, OP M-5, OP M-6, OP M-7, OP M-8, OP M-9, OP M-10, OP M-11, OP M-12, OP M-13, OP M-14, OP M-15, OP M-16, OP M-17, OP M-18, OP M-19, OP M-20, OP L-1, OP L-2, OP L-3, OP L-4, OP L-5, OP L-6, OP L-7, OP L-8) from the Operon kit were used for further analyses. In total, 128 polymorphic bands were obtained from these primers, an average of 4.57 bands per primer. The OP M-7 and OP M-14 primers were the most efficient at detection of polymorphism. The polymorphic locus average was $65 \%$, with the highest percentage of polymorphisms observed in the Valente population (73\%) and the smallest percentage observed in the Turvo population (55\%; Table 1).

\section{Statistical analyses}

The cut-off line represents the maximum similarity value $\left(s g_{m}\right)$ at the right of which the strains are considered to be similar. The $s g_{m}$ at the $1 \%$ probability level was 0.886 . The gen- 
eral dendrogram showed the formation of five groups, with the formation of three major clades in the Valente population. The genetic similarity estimates between the strains involving all five populations presented similarity amplitudes from 0.43 to 1.00 (Figure 1). The dendrograms generated for each population independently indicated that the isolates of G. cingulata f. sp phaseoli displayed significant intra-population diversity, with many haplotypes. Among the 200 strains, 57 genotypes did not group with any others. The Valente population presented the highest amplitude of similarity and formed the largest number of groups. Specifically, 34 of the 40 individuals of this group did not cluster with any other individuals (Table 1).

Table 1. Number and percentage of polymorphic loci, range of genetic similarity, Shannon index $(\mathrm{H})$, heterozygosity (HE), and number of groups formed by the five Glomerella cingulata f. sp phaseoli populations from Brazil.

\begin{tabular}{lcccrrr}
\hline Population & $\begin{array}{c}\text { Number of } \\
\text { polymorphic loci }\end{array}$ & $\begin{array}{c}\text { Percentage of } \\
\text { polymorphic loci (\%) }\end{array}$ & $\begin{array}{c}\text { Similarity } \\
\text { amplitude }\end{array}$ & $\begin{array}{c}\text { Number of } \\
\text { groups }\end{array}$ & H \\
\hline Guarapuava & 91 & 71.1 & $0.59-0.97(0.38)$ & 16 & 0.2010 \\
Majestoso & 85 & 66.4 & $0.60-1.00(0.40)$ & 9 & 0.1348 & 61.09 \\
Turvo & 70 & 54.7 & $0.80-1.00(0.20)$ & 7 & 0.0827 \\
Valente & 93 & 72.7 & $0.77-0.99(0.22)$ & 7 & 0.3171 \\
VCU & 80 & 62.5 & $0.54-0.97(0.43)$ & 34 & 0.1452 \\
\hline
\end{tabular}

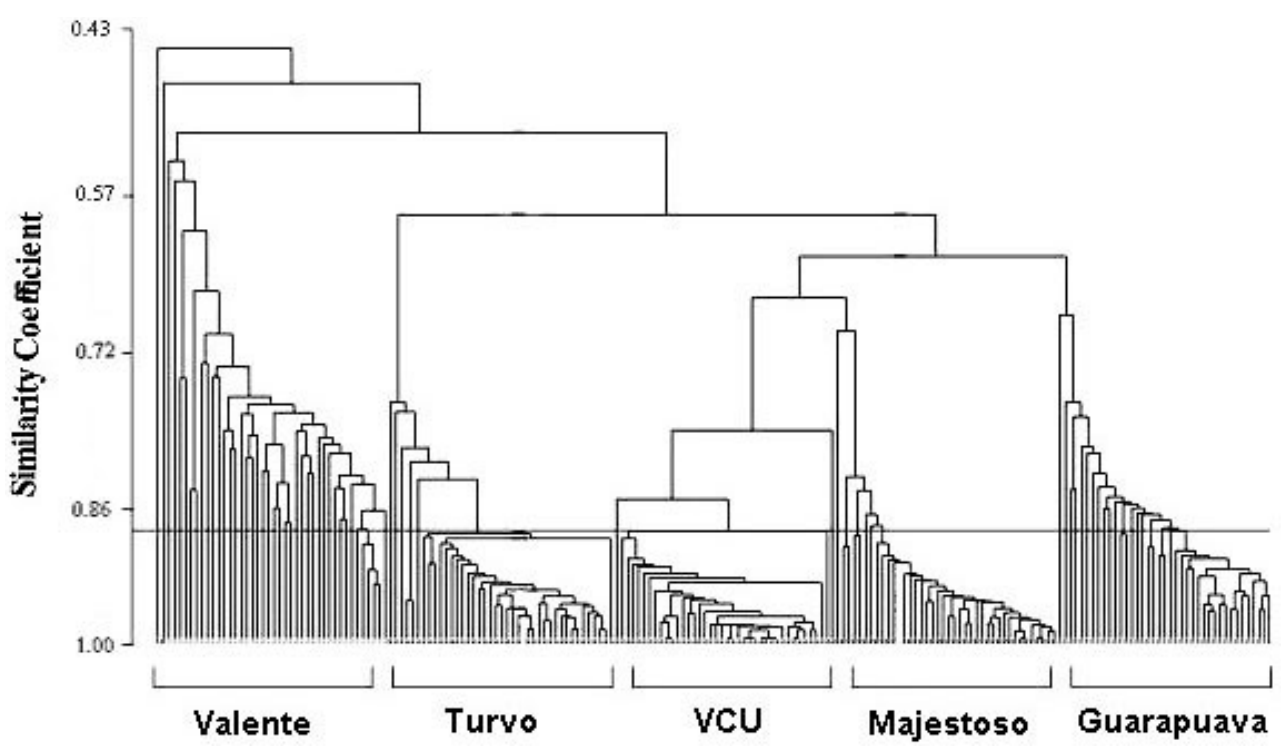

Figure 1. Cluster analyses of 200 Glomerella cingulata f. sp phaseoli isolates by UPGMA based on the genetic distance of Nei and Li (1979).

In order to measure the average contribution of sexual reproduction to genetic diversity presented in the evaluated populations, we compared published amplitudes of genetic similarity of asexual phase isolates (Table 2) with the amplitudes of genetic similarity of the sexual phase populations that we found (Table 1). We also calculated, the average contribution of the sexual phase to the amplification of genetic diversity of the pathogen (Table 3). 
Table 2. Summary of the number and origin of the isolates, the types of markers used in the analyses and the rate of similarity found in asexual phase populations of Colletotrichum lindemuthianum.

\begin{tabular}{|c|c|c|c|c|}
\hline Number of isolates & Origin of isolates & Marker used & Similarity amplitude & Reference \\
\hline 24 & Mexico & RAPD & $0.60-0.87$ & González et al., 1998 \\
\hline 49 & Mexico & AFLP & $0.92-1.00$ & Rodríguez-Guerra et al., 2003 \\
\hline 40 & South America & AFLP & $0.55-0.75$ & Ansari et al., 2004 \\
\hline 30 & Brazil & RAPD & $0.80-0.98$ & Talamini et al., 2006 \\
\hline 48 & Minas Gerais (Brazil) & RAPD & $0.70-0.99$ & Silva et al., 2007 \\
\hline 19 & Paraná (Brazil) & RAPD & $0.62-0.98$ & Silva et al., 2007 \\
\hline 49 & Brazil & RAPD & $0.90-0.99$ & Silva et al., 2007 \\
\hline
\end{tabular}

$\mathrm{RAPD}=$ random amplified polymorphic DNA; AFLP = amplified fragment length polymorphism.

Table 3. Estimated mean contribution of sexual reproduction to the expansion of genetic variability in Glomerella cingulata f. sp phaseoli populations compared to asexual population phases of the pathogen.

\begin{tabular}{lcccr}
\hline Populations & General averages & MG averages & PR averages & MG/PR averages \\
\hline Guarapuava & 0.17 & - & 0.02 & 0.06 \\
Majestoso & 0.19 & 0.11 & - & 0.08 \\
Turvo & -0.01 & - & -0.16 & -0.13 \\
Valente & 0.01 & -0.07 & - & -0.11 \\
VCU & 0.22 & 0.14 & - & 0.11 \\
\hline
\end{tabular}

Averages calculated by subtracting total genetic similarity amplitude (Table 2) from the mean amplitude of the asexual phase (Table 1). Minas Gerais (MG), Paraná (PR) and Minas Gerais/Paraná States.

The index of genetic diversity varied from 0.0827 to 0.3171 (Table 1). The lowest degree of diversity was detected in the Turvo population, and the greatest diversity was observed in the Valente population. The expected heterozygosity was also greater in the Valente population and smaller in the Turvo population (Table 1). The genetic diversity of the Nei value was decomposed, and we found that the total diversity between populations was $0.3647\left(H_{T}\right)$, indicating that $36 \%$ of the isolates are unique. Partition analyses of the genetic diversity for all 128 polymorphic loci showed significant genetic differentiation between the populations $\left(G_{S T}=0.6455\right)$.

Based on AMOVA, the genetic differentiation detected between sample populations was significant $\left(\Phi_{\mathrm{ST}}=0.69, \mathrm{P}<0.000\right)$, indicating that $69 \%$ of the genetic variation is between populations and $31 \%$ of the variation is found within the populations (Table 4).

Table 4. Summary of analysis of molecular variance of five Glomerella cingulata f. sp phaseoli populations from Brazil evaluated with random amplified polymorphic DNA markers.

\begin{tabular}{lrccccc}
\hline S.V. & d.f. & SS & Variance components & Total (\%) & $\Phi_{\text {ST }}$ & P \\
\hline Among populations & 4 & 3022.25 & 18.68 & 69.03 & 0.69 & 0.000 \\
Within populations & 195 & 1633.90 & 8.38 & 30.97 & & \\
Total & 199 & 4656.15 & 27.06 & 100 & \\
\hline
\end{tabular}

S.V. = sources of variation; d.f. $=$ degrees of freedom; $\mathrm{SS}=$ sum of squares.

The largest and smallest gametic disequilibria were detected for the Majestoso and Turvo populations, respectively. The gametic disequilibrium analyses, based on the Fisher test, generated values significantly different from zero, although the observed levels of linkage disequilibrium were low to moderate for all populations (Table 5). The number of combi- 
nations of loci in these analyses was $128 *(128-1) / 2=8128$. The multilocus association tests were also significant, showing that there is linkage disequilibrium between the five populations. However, considering that a value of $\bar{r}_{\mathrm{d}}=1.0$ indicates individual clones, the values determined in this study can be considered of low magnitude, as the largest $\bar{r}_{\mathrm{d}}$ value calculated was 0.1307 (Majestoso; Table 5).

\begin{tabular}{|c|c|c|c|}
\hline \multirow{2}{*}{ Populations } & \multirow{2}{*}{ Pairwise digenic linkage disequilibrium (\%) } & \multicolumn{2}{|c|}{ Indices of multilocus association } \\
\hline & & $I_{\mathrm{A}}$ & $\bar{r}_{\mathrm{d}}$ \\
\hline Guarapuava & 21.37 & 4.8747 & 0.05642 \\
\hline Majestoso & 27.32 & 10.2112 & 0.1307 \\
\hline Turvo & 11.66 & 3.6629 & 0.05707 \\
\hline Valente & 15.31 & 2.4999 & 0.0278 \\
\hline $\mathrm{VCU}$ & 15.62 & 4.6826 & 0.0658 \\
\hline
\end{tabular}

\section{DISCUSSION}

Anthracnose of the common bean is characterized by characteristic symptoms, including depressed and dark-colored oval lesions in pods and stems and dark stains along the veins of leaves. However, absence of such symptoms in plants inoculated with G. cingulata f. sp phaseoli isolates has been reported (Camargo Jr. et al., 2007; Ishikawa et al., 2009); the symptoms in the sexual phase are milder than those presented during the asexual phase.

Although no fertile crosses were obtained from the combinations of isolates that we used, recombination between G. cingulata f. sp phaseoli isolates has been reported (Rodríguez-Guerra et al., 2005; Camargo Jr. et al., 2007). In fact, atypical sexual behavior in Colletotrichum species, with both heterothallic and homothallic forms, has been described (Rodríguez and Owen, 1992; Cisar and TeBeest, 1999; Vaillancourt et al., 2000).

The general dendrogram demonstrated five distinct groups within the sampled populations. These groups correspond to the five populations that we analyzed, even though these populations were isolated from nearby regions. This form of local adaptation has been reported in several host-pathogen interactions (Thompson, 1994; Kaltz and Shykoff, 1998). Coevolution can become evident in complex hierarchical levels, when several plants are sampled at different times of the year, and also in more simple hierarchical levels, such as in populations of a few plants, a single plant, or even in a single lesion, when these events occur in pathogens with reduced genetic flow between geographic units. The evolutionary advantage of the pathogen in relation to its host is characterized by the fact that the pathogen adapts to changes in the local host population, principally because the $C$. lindemuthianum life cycle is up to 10 times shorter than that of the wild common bean (Capelle and Neema, 2005).

We analyzed populations originating from a few common bean plants derived from agroecosystems; this permitted clear separation of the five populations. This population structure indicates that this pathogen is dispersed at a fine scale, a fact that directly interferes with genetic flow and recombination between populations. Capelle and Neema (2005), who studied asexual phase isolates and wild populations, reported that this population structure is typical for this pathogen. Even during heavy storms, maximum dispersal of G. cingulata f. sp pha- 
seoli spores is a few meters $(\mathrm{Tu}, 1992)$. It is probable that the dispersal of the spores occurs preferentially between different parts of the same plant and occasionally between adjacent plants. Thus, diversity is generated and maintained in simple hierarchic levels.

In spite of the results demonstrating these evolutionary dynamics in the G. cingulata f. sp phaseoli $\mathrm{x} P$. vulgaris interaction on a reduced scale, the origin of the genetic diversity that was found remains unclear. It is believed that selection pressure by the host and the alternation of sexual and asexual phases are keys to explaining this diversity (Ruey-Shyang and McDonald, 1996). An entirely asexual population has high frequencies of clonal individuals, with a few genotypes at an especially high frequency. In our study, the G. cingulata f. sp phaseoli populations were characterized by considerable genetic diversity. Comparing the data obtained from sexual populations with published data on asexual populations, we can infer the capability of sexual reproduction to amplify genetic variability in this pathogen. Considering data from Silva et al. (2007) in an analysis of the asexual phase of the pathogen in populations from the State of Minas Gerais, Brazil, the extent of similarity ranged from 0.70-0.99, with $29 \%$ dissimilarity. The G. cingulata f. sp phaseoli strains that we collected from Minas Gerais presented similarities of $0.54-0.97$ and dissimilarity of $43 \%$. This difference in the diversity values between the sexual and asexual populations indicates that recombination plays a fundamental role in the expansion of variability in populations of this pathogen. In addition to the characterization of variability in the populations, we identified few clonal lines. The Turvo population had the largest number of clonal lines, a result that is expected based on its low degree of similarity and reduced number of groups formed in the dendrogram. This implies that the Turvo population originated from several cycles of asexual reproduction, which may have obscured the contributions of sexual reproduction (Ruey-Shyang and McDonald, 1996). Larger-scale studies characterizing the population structure of this pathogen with regards to its sexual and asexual phases are needed to resolve these questions.

Analysis of the partition of diversity of this species supports the hypothesis that the spore of this pathogen disperses only a short distance from the source (Table 4). One possible reason for the different levels of genetic diversity observed in each of the populations that we examined is that the pathogen interacts with the different host cultivars at each location and consequently interacts with different genetic backgrounds. In this case, the host diversity would influence the maintenance of the genotype diversity of the pathogen (Rodríguez-Guerra et al., 2003). The differences observed between populations are consistent with the fact that they did not produce compatible crosses, suggesting reproductive isolation between the five populations, which resulted in significant variability between the different sample locations.

Results of analyses of digenic and multilocus gametic disequilibrium demonstrate significant levels of linkage disequilibrium, although these levels may be considered low to moderate in comparison with the disequilibrium presented by a clonal population. Based on these results, some level of clonality exists in the G. cingulata f. sp phaseoli population, though recombination is still possible. However, the data demonstrate a genetic structure consistent with sexual reproduction for this pathogen (Schmale et al., 2006). In addition, the estimates generated by multilocus associations for other species with a known sexual phase (Rau et al., 2003) are similar to those calculated in our study.

Colletotrichum lindemuthianum have been described as an asexual pathogen. However, regional-scale studies have demonstrated levels of linkage disequilibrium consistent with recombination, suggesting that sexual reproduction is more frequent under field conditions 
than previously thought (Capelle and Neema, 2005). This observation can be explained by a low capacity for dispersion of spores, founder effects and selection pressure exerted by host-resistance genes. In Brazil, the common bean is cultivated in three distinct seasons, an approach that pressures the pathogen towards sexual recombination in order to respond to environmental changes. It is likely that the sexual cycle is triggered at some stage of the pathogen's population development, resulting in an expansion of genetic variability. Following this expansion, several asexual reproduction cycles would take place, as the asexual phase of the pathogen is responsible for the epidemiological phase of infection.

\section{ACKNOWLEDGMENTS}

The authors thank Conselho Nacional de Desenvolvimento Científico e Tecnológico $(\mathrm{CNPq})$ and Fundação de Amparo à Pesquisa do Estado de Minas Gerais (FAPEMIG) for scholarships and financial support. We also thank Dr. Diogo Gonçalves Neder for helpful discussions concerning the statistical analysis.

\section{REFERENCES}

Agapow PM and Burt A (2001). Indices of multilocus linkage disequilibrium. Mol. Ecol. Notes 1: 101-102.

Ansari KI, Palacios N and Araya C (2004). Patogenic and genetic variability among Colletotrichum lindemuthianum isolates of different geographic origins. Plant Pathol. 53: 635-642.

Bock CH, Thrall PH and Burdon JJ (2005). Genetic structure of populations of Alternaria brassicicola suggests the occurrence of sexual recombination. Mycol. Res. 109: 227-236.

Brown AHD, Feldman MW and Nevo E (1980). Multilocus structure of natural populations of Hordeum spontaneum. Genetics 96: 523-536.

Burt A, Koufopanou V and Taylor JW (1999). The Molecular Epidemiology of Infectious Diseases: Population Genetics of Human-Pathogenic Fungi (Thompson RCA, ed.). Chapman and Hall, London, 229-244.

Camargo OA Jr, Souza EA, Mendes-Costa MC, Santos JB, et al. (2007). Identification of Glomerella cingulata $\mathrm{f} . \mathrm{sp}$ phaseoli recombinants by RAPD markers. Genet. Mol. Res. 6: 607-615.

Capelle J and Neema C (2005). Local adaptation and population structure at a micro-geographical scale of a fungal parasite on its host plant. J. Evol. Biol. 18: 1445-1454.

CIAT (International Center of Tropical Agriculture) (1990). Informe Anual. Programa de Frijol, Cali.

Cisar CR and TeBeest DO (1999). Mating system of the filamentous ascomycete, Glomerella cingulata. Curr. Genet. 35: 127-133.

Gonzalez M, Rodriguez R, Zavala ME, Jacobo JL, et al. (1998). Characterization of Mexican isolates of Colletotrichum lindemuthianum by using differential cultivars and molecular markers. Phytopathology 88: 292-299.

Ishikawa FH, Barcelos QL, Alves E, Camargo Junior AO, et al. (2009). Symptoms and prepenetration events associated with the infection of common bean by the anamorph and teleomorph of Glomerella cingulata f. sp. phaseoli. J. Phytopathol. 158: 270-277.

Junqueira NTV, Chaves GM, Zambolin L and Romeiro RS (1984). Isolamento, cultivo e esporulação de Microcyclus ulei, agente etiológico do mal das folhas da seringueira. Rev. Ceres 31: 322-331.

Kaltz O and Shykoff JA (1998). Local adaptation in host-parasite systems. Heredity 81: 361-370.

Kistler HC and Miao VP (1992). New modes of genetic change in filamentous fungi. Annu. Rev. Phytopathol. 30: 131-153.

Mendes-Costa MC (1996). Genetics of Glomerella cingulata f. sp. phaseoli I. Sexual Compatibility. In: Anais do $42^{\circ}$ Congresso Nacional de Genética, Caxambu.

Nei M (1973). Analysis of gene diversity in subdivided populations. Proc. Natl. Acad. Sci. U. S. A. 70: 3321-3323.

Nei M and Li WH (1979). Mathematical model for studying genetic variation in terms of restriction endonucleases. Proc. Natl. Acad. Sci. U. S. A. 76: 5269-5273.

Paula Junior TJ, Vieira RF, Teixeira H, Coelho RR, et al. (2008). Informações Técnicas para o Cultivo do Feijoeiro Comum na Região Central Brasileira: 2007-2009. EPAMIG (Série de Documentos, 42), Viçosa.

Raeder U and Broda P (1985). Rapid preparation of DNA from filamentous fungi. Lett. Appl. Microbiol. 1: 17-20.

Rau D, Brown AHD, Brubaker CL, Attene G, et al. (2003). Population genetic structure of Pyrenophora teres Drechs. the 
causal agent of net blotch in Sardinian landraces of barley (Hordeum vulgare L.). Theor. Appl. Genet. 106: 947-959.

Rava CA, Molina J, Kauffmann M and Briones I (1993). Determinación de razas fisiológicas de Colletotrichum lindemuthianum em Nicaragua. Trop. Plant. Pathol. 18: 388-391.

Raymond M and Rousset F (1995). GENEPOP (version 1.2): Population genetics software for exact tests and ecumenicism. J. Hered. 86: 248-249.

Roca MG, Davide LC, Mendes-Costa MC and Wheals A (2003). Conidial anastomosis tubes in Colletotrichum. Fungal Genet. Biol. 40: 138-145.

Rodríguez R and Owen JL (1992). Isolation of Glomerella musae (Teleomorph of Colletotrichum musae [Berk. \& Curt.] Arx) and segregation of ascospore progeny. Mycol. Res. 16: 291-301.

Rodríguez-Guerra R, Ramírez-Rueda MT, Martinez O and Simpson J (2003). Variation in genotype, pathotype and anastomosis groups of Colletotrichum lindemuthianum isolates from Mexico. Plant Pathol. 52: 228-235.

Rodríguez-Guerra R, Ramírez-Rueda MT, Cabral-Enciso M, Garcia-Serrano M, et al. (2005). Heterothallic mating observed between Mexican isolates of Glomerella lindemuthiana. Mycologia 97: 793-803.

Rohlf FJ (2000). NTSYSpc, Numerical Taxonomy and Multivariate Data Analysis System, ver. 2.01. Exeter Software: Setauket, New York.

Ruey-Shyang C and McDonald B (1996). Sexual reproduction plays a major role in the genetic structure of populations of the fungus Mycosphaerella graminicola. Genetics 142: 1119-1127.

Schmale DG, Leslie JF, Zeller KA and Saleh AA (2006). Genetic structure of atmospheric populations of Gibberella zeae. J. Phytopathol. 96: 1021-1026.

Schneider S, Roessli D and Excoffier L (2000). Arlequin ver. 2.000: A Software for Population Genetic Data Analysis. Genetics and Biometry Laboratory, University of Geneva, Geneva.

Shannon CE (1948). A mathematical theory of communication. Bell System Tech. 27: 379-423, 623-656.

Shear CL and Wood AK (1913). Studies of fungus parasites belonging to the genus Glomerella. U.S. Department of Agriculture Bureau of Plant Industry (Bulletin No. 252), Washington.

Silva KJD, Souza EA and Ishikawa FH (2007). Characterization of Colletotrichum lindemuthianum isolates from the state of Minas Gerais, Brazil. J. Phytopathol. 155: 241-247.

Skroch P, Tivang J and Nienhuis J (1992). Analysis of genetic relationships using RAPD marker data. Applications of RAPD Technology to Plant Breeding. Crop Science Society of America, Minneapolis, 26-20.

Talamini V, Souza EA, Pozza EA, Fernandes FR, et al. (2006). Divergência genética entre e dentro de raças de Colletotrichum lindemuthianum por meio de marcadores RAPD. Summa Phythopatol. 32: 23.

Thompson JN (1994). The Coevolutionary Process. University of Chicago Press, Chicago.

Tu JC (1992). Colletotrichum: Biology, Pathology and Control: Colletotrichum lindemuthianum on Bean. Population Dynamics of the Pathogen and Breeding for Resistance (Baily JA and Jege MJ, eds.). CAB. International, Wallingford, 203-224.

Vaillancourt L, Wang J and Hanau R (2000). Colletotrichum: Host Specificity, Pathology, and Host-Pothogen Interaction: Genetic Regulation of Sexual Compatibility in Glomerella graminicola (Prusky D, Freeman S and Dickman MB, eds.). APS Press, St. Paul, 29-44. 